RASĀYAN J. Chem.

Vol. 12 | No. 3 |1569 - 1574| July - September | 2019

ISSN: 0974-1496 | e-ISSN: 0976-0083 | CODEN: RJCABP

RJC

http://www.rasayanjournal.com

http://www.rasayanjournal.co.in

\title{
BIOCHEMICAL EVALUATION OF DUKU'S MISTLETOE LEAVE (Dendrophthoepentandra (L.) Miq) EXTRACT WITH ANTIDIABETIC POTENTIAL
}

\author{
Rini Hardiyanti ${ }^{1}$, Lamek Marpaung ${ }^{1, *}$, I. Ketut Adnyana ${ }^{2}$ \\ and Partomuan Simanjuntak ${ }^{3,4}$
}

${ }^{1}$ Department of Chemistry, Faculty of Mathematics and Natural Sciences, Universitas Sumatera

Utara, Padang Bulan, Medan 20155, Indonesia.

${ }^{2}$ Department of Pharmacology, Faculty of Pharmacy, Institut Teknologi Bandung,

Jl. Ganesha, Bandung 40132, Indonesia.

${ }^{3}$ Department of Natural Product Chemistry, Research Centre for Biotechnology, Indonesian Institute of Science, J1. Raya Bogor Km 46, Cibinong 16911, Indonesia.

${ }^{4}$ Faculty of Pharmacy, Universitas Pancasila, Jl. Srengseng Sawah,

Jagakarsa, Jakarta, 12640, Indonesia

*E-mail: toyamaikayakadai@yahoo.co.id

\begin{abstract}
Inhibition of $\alpha$-glucosidase is a method used to identify bioactive secondary metabolite that has the potency to treat diabetic. The aim of this study was to evaluate the biochemical activity (i.e. antioxidant and inhibition of $\alpha$ glucosidase) of four different types of Dendrophthoepentandra (L.) Miq leaves extract through the $\alpha$-glucosidase inhibitory method. The extracts were obtained using maceration and column chromatography methods. The resulted in four extracts of Dendrophthoepentandra (L.) Miqleaves, such as extract of methanol, n-hexane, ethyl acetate, and total flavonoid. The $\alpha$-glucosidase inhibitory effect of Dendrophthoepentandra (L.) Miq leaves extract was carried out using a spectrophotometer. The greatest inhibition of $\alpha$-glucosidase was found in total flavonoid with $\mathrm{IC}_{50}$ value of 57,29 $\pm 0,63 \mathrm{ppm}$. These total flavonoid leaves extract can be proposed as a potential antidiabetic agent.
\end{abstract}

Keywords: Dendrophthoepentandra (L.) Miq, Flavonoid, Antidiabetic

(C) RASĀYAN. All rights reserved

\section{INTRODUCTION}

Diabetes mellitus is a metabolic disease caused by the disfunction of the pancreas to secrete insulin. The lack of insulin secretion causes the impairment of carbohydrate metabolism and result in high plasma glucose levels (hyperglycemic) ${ }^{1}$. The number of diabetes mellitus patients increases every year, in Indonesia increases by $8.5 \%$ in 2018 from $6.9 \%$ in 2013 and in 2030 the number of diabetics will be 21.3 million $^{2}$. Those increasing have been followed by the increasing number of potential researches to discover new active metabolite that has great potency to cure diabetic from plant sources. ${ }^{3,4}$ The plant families that having anti-diabetic properties can be used as a safer hypoglycemic agent ${ }^{5}$.In the previous works, the plant that has biochemical activity possess with a composite of the bioactive compound, such as flavonoid, alkaloid, saponin, phenolic, vitamin, etc. ${ }^{6-8}$

Some of the new active metabolites that were discovered by Mohan et al ${ }^{9}$, Keshari et al ${ }^{10}$, Jiang et al ${ }^{11}$ and Nambirajan et $\mathrm{al}^{12}$ were categorized as a flavonoid. In the previous work, flavonoid compound was declared as a secondary metabolite with a lot of bioactivities, such as antibacterial, anticancer and antidiabetic.

The bioactive compound that refers to secondary metabolites is formed in the plant during normal metabolic process ${ }^{13}$. Also, in the previous works, the ancient Indian literature, Ayur Veda, was used as the

Rasayan J. Chem., 12(3), 1569-1574(2019)

http://dx.doi.org/10.31788/RJC.2019.1235272

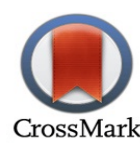


RASĀYAN J. Chem.

Vol. 12 | No. 3 |1569 - 1574| July - September | 2019

basic information to provide herbal plants that effective in the treatment of disease and nowadays the need of the medicinal plants has increase to come across the demand of modern medicine $e^{10,14}$.

In our previous studies, the leaves extract of mistletoe leave Dendrophthoepentandra (L.) Miq of Duku (Lansium domesticum Cor.r) has a great potency as an antioxidant that caused by the high total flavonoid content $^{15}$. However, till-date a systematic study on biological activities of leaves extract of $D$. (L.) Miq. is still not conducted. The extensive literature survey exposed that only a few reports exist on this plant leaves, but no information is available on anti-diabetic activity in particular. Henceforth, the objective of this study was to analyze the inhibitory activity of D.pentandra (L.) Miqleaves extracts to in vitro $\alpha$ glucosidase.

This objective was based on the previous work, there is a correlation between the inhibition of $\alpha$ glucosidase and the phenolic/ flavonoid compound in the plant. It means phenolic/ flavonoid compound can act as an antioxidant and $\alpha$-glucosidase inhibitor. ${ }^{16}$

\section{EXPERIMENTAL}

\section{Material}

The leaves of Dendrophthoepentandra (L.) Miq were obtained from Medan Johor, Sumatera Utara, Indonesia. The taxonomy determination was conducted in Herbarium Bogoriense, LIPI, CibinongIndonesia.

\section{Preparation of Plant Extract}

The maceration and fractionation process was conducted by following the previous method ${ }^{15}$. D.pentandra (L.) Miq leaves were dried and powdered. The dried leaf powder was macerated using methanol and filtered after $48 \mathrm{~h}$. The solvent in the filtrate was evaporated and to eliminate tannin, the concentrated extract of methanol was partitioned using water and ethyl acetate. The obtained fraction then evaporated to remove the solvent. In order to obtain total flavonoid fraction, the concentrated extract was partitioned with methanol and n-hexane. The separation process of the flavonoid component was performed using column chromatography with the ratio of sample and silica gel was 1: 30 . Silica gel was used as stationary phase and the mobile phase for this process was the mixture of polar-nonpolar solvent, chloroform and methanol, with the ration 9:1, 8:2, 7:3 and 6:4.

\section{Antidiabetic Assay by $\alpha$-Glucosidase Inhibitory Method}

The $\alpha$-glucosidase inhibitory activity of the methanol, $n$-hexane, ethyl acetate and total flavonoid extracts of D.pentandra (L.) Miq leaves were determined using in-vitro method (Table-1). The dried residue (extract) was re-dissolved in methanol and the concentration was variated to be 50,100, 250, 500 and $1000 \mathrm{ppm}$. A mixture of $25 \mu \mathrm{L}$ of sample (extract), $475 \mu \mathrm{L}$ of $0.1 \mathrm{M}$ phosphate buffer (pH 6.9) and $250 \mu \mathrm{L}$ of $0.5 \mathrm{mMpNPG}$ solution was incubated at $37^{\circ} \mathrm{C}$ for 5 minutes. After pre-incubation, $250 \mu \mathrm{L}$ of $0.01 \mathrm{M}$ phosphate buffer ( $\mathrm{pH}$ 6.9) containing $\alpha$-glucosidase solution $(0.04 \mathrm{U} / / \mathrm{mL})$ was added to the previous solution. The reaction mixture was incubated at $37{ }^{\circ} \mathrm{C}$ for $25 \mathrm{~min}$, after this incubation $1000 \mu \mathrm{L}$ of 0.2 $\mathrm{Na}_{2} \mathrm{CO}_{3}$ was added into the solution. Before and after incubation, absorbance was recorded at $405 \mathrm{~nm}$ by micro plate reader. The $\alpha$-glucosidase inhibitory activity was expressed as percentage inhibition percent and was calculated as follows:

Where:

$$
\% \text { Inhibitory Activity }=[(\mathrm{C}-\mathrm{S}) / \mathrm{C}] \mathrm{X} 100
$$

$\mathrm{C}=$ control absorbance (blank)

$\mathrm{S}=$ sample absorbance (S1-S0)

Table-1: The Formulation for $\alpha$-Glucosidase Inhibitory Assay

\begin{tabular}{c|c|c|c|c}
\hline & $\begin{array}{c}\text { Control } \\
(\mu \mathrm{L})\end{array}$ & $\begin{array}{c}\text { Blank } \\
(\mu \mathrm{L})\end{array}$ & $\begin{array}{c}\text { S1 } \\
(\mu \mathrm{L})\end{array}$ & $\begin{array}{c}\text { S0 } \\
(\mu \mathrm{L})\end{array}$ \\
\hline Sample *) & - & - & 25 & 25 \\
\hline DMSO 1\% & 25 & 25 & - & - \\
\hline 0.1 M phosphate buffer & 475 & 475 & 475 & 475 \\
\hline
\end{tabular}


RASĀYAN J. Chem.

Vol. 12 | No. 3 |1569 - 1574| July - September | 2019

\begin{tabular}{c|c|c|c|c}
\hline $0.5 \mathrm{mMpNPG}$ solution & 250 & 250 & 250 & 250 \\
\hline \multicolumn{5}{c}{ Incubated at $37^{\circ} \mathrm{C}$ for $5 \mathrm{~min}$} \\
\hline 0.04 unit/mL $\alpha$-Glucosidase & 250 & - & 250 & - \\
\hline 0.01 phosphate buffer & - & 250 & - & 250 \\
\hline \multicolumn{7}{c}{ Incubated at $37^{\circ} \mathrm{C}$ for $25 \mathrm{~min}$} \\
\hline $0.02 \mathrm{M} \mathrm{Na}_{2} \mathrm{CO}_{3}$ & 1000 & 1000 & 1000 & 1000 \\
\hline
\end{tabular}

*) Sample was prepared in various concentration: 50, 100, 250, 500 and $1000 \mathrm{ppm}$.

\section{RESULTS AND DISCUSSION}

The crude extract of D.pentandra (L.) Miq leaves exhibited the presence of flavonoids and terpenoid or steroid (Table-1). ${ }^{17}$ Also, those phytochemical constituents in various extracts showed the high antioxidant activity that measured using DPPH method (Fig.-1).

Table-1: Phytochemical Screening of D.pentandra (L.) Miqleaves

\begin{tabular}{c|c|c|c}
\hline No. & Secondary Metabolite & Reagent & Result \\
\hline 1 & Alkaloid & Meyer & - \\
\hline & & Buchardat & - \\
\hline & & Dragendorf/Wagner & ++++ \\
\hline 2 & Flavonoid & Ethyl acetate extract $+\mathrm{FeCl}_{3} 1 \%$ & ++++ \\
\hline & & Methanol extract $+\mathrm{FeCl}_{3} 1 \%$ & + \\
\hline 4 & Saponin & Lieberman Bouchard & +++ \\
\hline 5 & Terpenoid/steroid & $\mathrm{CeSO}_{4} 1 \%$ in $\mathrm{H}_{2} \mathrm{SO}_{4}$ using TLC plate & \\
\hline
\end{tabular}

P.S.: (Negative) and + (Positive)

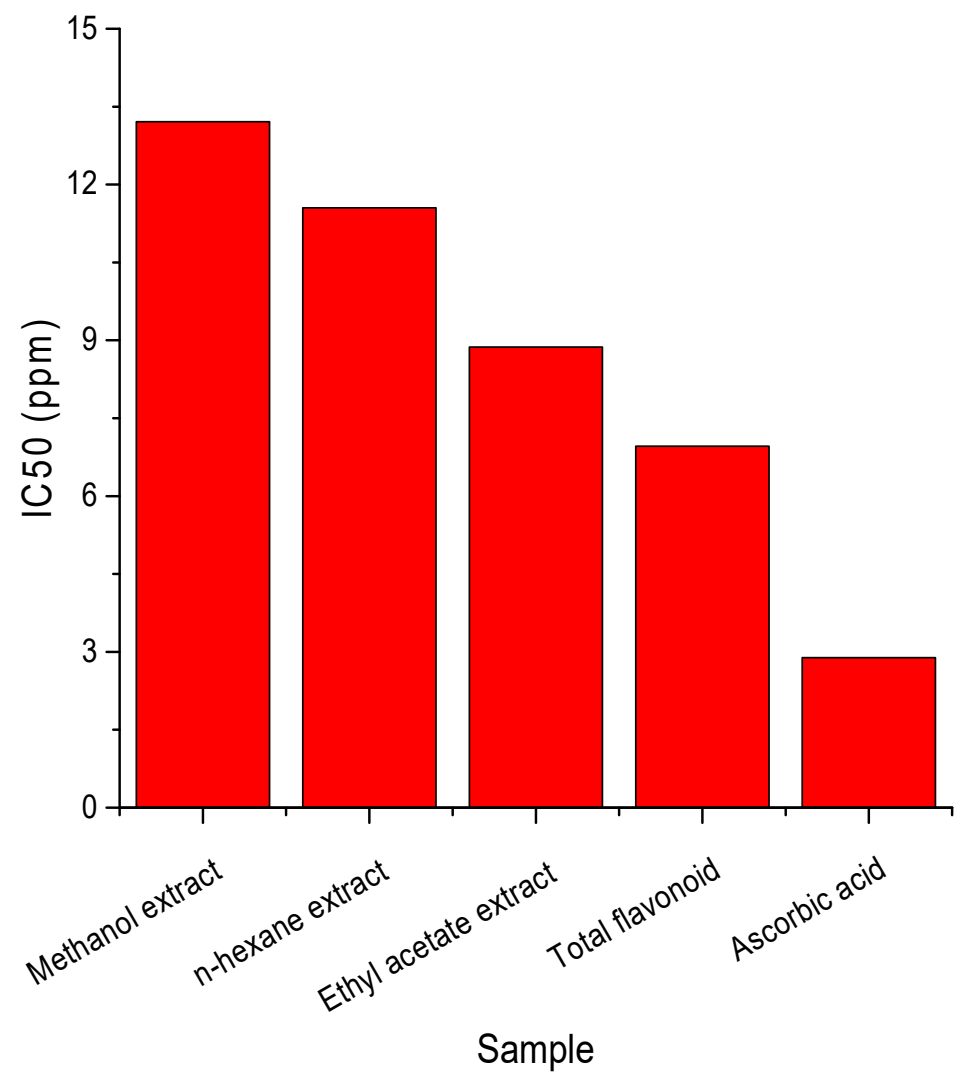

Fig.-1: The $\mathrm{IC}_{50}$ Values of Methanol Extract, n-Hexane Extract, Ethyl Acetate Extract, Total Flavonoid, and Ascorbic Acid againts1,1-Diphenyl-2- Picrylhydrazyl 
RASĀYAN J. Chem.

Vol. 12 | No. 3 |1569 - 1574| July - September | 2019

The antioxidant activities of D.pentandra (L.) Miq was shown as $\mathrm{IC}_{50}$ values that showed in Fig.-1. The ascorbic acid in this study was used as the positive control and it showed the highest $\mathrm{IC}_{50}$ value of 2.89 $\mu \mathrm{g} / \mathrm{mL}$. In this study, all four extracts had a lower activity as an antioxidant than ascorbic acid. The DPPH radical scavenging ability from the total flavonoid extract was four times lower than the reference compound (Fig.-1). The second higher DPPH radical scavenging ability observed in the total flavonoid could be attributed to the synergy effect of flavonoid compound in the leaves (Fig.-1) which contain a lot of hydroxyl groups $(\mathrm{OH})$ which take part in antioxidant reactions. ${ }^{18,19}$

As a report in the previous work, the position and the number of hydroxyl group mostly affect the antioxidant activity of flavonoid compounds, especially in the mechanism to inhibit free radical, i.e. radical scavenging and metal chelation. Compare to ring $\mathrm{A}$ and $\mathrm{C}$, the change of the hydroxyl group in ring $\mathrm{B}$ give a significant result to the antioxidant activity. This phenomenon based on the ability of this ring to donate an electron to the free radical molecules and make them stable ${ }^{20}$.

Recent research showed the $\alpha$-glucosidase inhibition concepts was one effective approach to evaluate the correlation of secondary metabolite activity to control diabetes. The $\alpha$-glucosidase inhibition of $n$-hexane, ethyl acetate, methanol, and total flavonoid extracts of D.pentandra (L.) Miq are given in Table-2.The alpha-glucosidase inhibitory activity of the n-hexane, ethyl acetate, methanol, and total flavonoid extracts of D.pentandra (L.) Miq was observed to be in a concentration-dependent manner.

The total flavonoid extracts had higher antidiabetic activity compared to the other extract of D.pentandra (L.) Miq. In this study, this was considered to be a good activity. This activity was supported with the antioxidant data that also showed the total flavonoid extract has antioxidant activity compared to the other extract.

Table-2: Antidiabetic Assay of D.pentandra (L.) Miq

\begin{tabular}{|c|c|c|c|}
\hline Sample & Concentration (ppm) & Inhibition $(\%)$ & $\mathrm{IC}_{50}(\mathrm{ppm})$ \\
\hline \multirow{5}{*}{ Methanol Extract } & 6,25 & 10,814 & \\
\hline & 12,5 & 20,671 & \\
\hline & 25 & 34,853 & $78,26 \pm 0,14$ \\
\hline & 50 & 45,189 & \\
\hline & 100 & 54,570 & \\
\hline \multirow{5}{*}{$\begin{array}{c}\text { Ethyl Acetate } \\
\text { Extract }\end{array}$} & 6,25 & 4,697 & \\
\hline & 12,5 & 10,564 & \\
\hline & 25 & 18,786 & $94,97 \pm 0,30$ \\
\hline & 50 & 32,096 & \\
\hline & 100 & 50,489 & \\
\hline \multirow{5}{*}{ n-Hexaneextract } & 6,25 & 1,369 & \\
\hline & 12,5 & 2,934 & \\
\hline & 25 & 3,716 & $221,83 \pm 11,26$ \\
\hline & 50 & 16,438 & \\
\hline & 100 & 21,136 & \\
\hline \multirow{5}{*}{ Total Flavonoid } & 6,25 & 2,880 & \\
\hline & 12,5 & 7,451 & \\
\hline & 25 & 32,205 & $57,29 \pm 0,63$ \\
\hline & 50 & 35,578 & \\
\hline & 100 & 89,662 & \\
\hline
\end{tabular}


RASĀYAN J. Chem.

Vol. 12 | No. 3 |1569 - 1574| July - September | 2019

\section{CONCLUSION}

Dendrophtoepentandra (L.) Miq leaves have been extracted using several solvents and it showed bioactivity potency as antioxidant and antidiabetic. From the four kinds of $D$. pentandra (L.) Miq leave extract, the extract of total flavonoid showed the highest activities in the antioxidant and antidiabetic test than the other extract.

\section{ACKNOWLEDGMENT}

Our thanks to the Ministry of Research Technology and Higher Education (KEMENRISTEK DIKTI) through PMDSU scholarship which has funded this research and Department of Natural Product Chemistry (LIPI) which has facilitated a laboratory for this research.

\section{REFERENCES}

1. T.O. Obafemi, C.A. Akinmoladun, M.T. Olaleye, S.O. Agboade and A.A. Onasanya, Journal Ayurveda Integr. Med., 8(1), (2017), DOI:10.1016/j.jaim.2017.01.008

2. W. Aligita, S. Muhsinin, E. Susilawati, Dahlia, D.S. Pratiwi, D. Aprilliani, A. Artarini, and I. K. Adnyana. Rasayan J. Chem., 12(1), 157 (2019), DOI:10.31788/RJC.2019.1215059

3. T. Wresdiyati, S.Sa'diah, A. Winarto, and V. Febriyani. Hayati J. Biosci., 22(2), 73 (2015), DOI: $10.4308 / \mathrm{hjb} .22 .2 .73$

4. A.K. Shettar, M.K. Sateesh, B.B. Kaliwal, and A.B. Vedamurthy. South African J. Bot., 111, 202 (2017), DOI:10.1016/sajb.2017.03.014

5. C. Sunil, P. Agastian, C. Kumarappan, and S. Ignacimuthu. Food Chem. Toxicol., 50, 1547 (2012), DOI:10.1016/j.fet.2012.01.029

6. J.A.O. Olugbuyiro, A.S. Banwo, A.O. Adeyemi, O.S. Taiwo, and O.A. Akintokun. Rasayan J. Chem., 11(2), 798 (2018), DOI:10.31788/RJC.2018.1121823

7. T. Okselni, A. Santoni, A. Dharma, and M. Efdi. Rasayan J. Chem., 11, (2018), DOI: 10.31788/RJC.2018.1133058

8. M.Y. Lubis, R. Siburian, L. Marpaung, P. Simanjuntak, and M.P. Nasution. Asian J. Pharm. Clin. Res., 11(1), 346 (2018), DOI:10.22159/ajpcr.2018.v11i1.21637

9. S. Mohan, and L. Nandhakumar. J. Med. Hypotheses Ideas, 8, (2014), DOI:10.1016/jjmhi.2013.06.001

10. A.K. Keshari, G. Kumar, P.S. Kushwaha, M. Bhardwaj, P. Kumar, and A. Rawat, et al., J. Ethnopharmacol, 181, 252 (2016), DOI:10.1016/j-jep.2016.02.004

11. W. Jiang, L. Si, P. Li, B. Bai, J. Qu, and B. Hou, et al., J. Chromatogr B Anal. Technol. Biomed. Life Sci., 1092, 466 (2018), DOI:10.1016/j/jchomb.2018.06.041

12. G. Nambirajan, K. Karunanidhi, A. Ganesan, R. Rajendran, R. Kandasamy, and A. Elangovan, et al., Biomed Pharmacother, 108, 1495 (2018), DOI:10.1016/j.biopha.2018.10.007

13. P. B. Mallikhurjana, L.N. Rajanna, Y.N. Seetharam, and G. K. Sharanabasappa, J. Chem., 4(4), 510 (2007).

14. V.P. Kumar, N.S. Chauhan, H. Padh, and M. Rajani, J. Ethnopharmacol, 107, (2006), DOI:10.1016/j.jep.2006.03.013

15. R. Hardiyanti, L. Marpaung, I.K. Adnyana, P. Simanjuntak, Asian J. Pharm. Clin. Res., 11(12), (2018), DOI:10.22159/ajpcr.2018.v11i12.29725

16. P. Pramai, N. A. A. Hamid, A. Mediani, M. Maulidiani, F. Abas and S. Jiangyangyuen, J. Food Drug Anal, 26, (2017), DOI:10.1016/j.jfda.2016.11.023

17. R. Hardiyanti, L. Marpaung, P. Simanjuntak, I.K. Adnyana. In: The 7th AIC-ICMR on Health and Life Sciences The Annual International Conference 2017 Syiah Kuala University. 2017, pp 45-53.

18. D. Sumaiyah, Masfriyah, Rasayan J. Chem., 11, (2018), DOI:10.31788/RJC.2018.1122068 1573 
RASĀYAN J. Chem.

Vol. 12 | No. 3 |1569 - 1574| July - September | 2019

19. A.E. Hagerman, K.M. Riedl, G.A. Jones, K.N. Sovik, N.T. Ritchard and P.W. Hartzfeld, et al., J. Agric. Food Chem. (1998).

20. S. Kumar and A.K. Pandey, The Scientific World Journal, (2013), DOI:10.1155/2013/162750

[RJC-5272/2019] 